\title{
Best Strategies in Developing Student Spiritual Attitude at IAKN Tarutung
}

\author{
Uranus Zamili, M.Pd.K \\ IAKN Tarutung North Sumatera Indonesia \\ uranuszamili87@gmail.com
}

\begin{abstract}
This study aims to present the positive sides of the research result dealing with the learners attitude.The more sophisticated the era the worse attitude the millennial students have so far, and such a problem becomes a challenge for educators. This study belongs to qualitative research by using observation and interview approach in gathering the data. To analyze the obtained data that had been administered, it was presented at the data display and transforming the responses from the sample by using descriptive qualitative method. The result was that lecturers of Christian Religious Education should make a strategic effort to develop the ability of spiritual attitude. In this article, the focus of the strategy was concerning on the factors and obstacles and improving students' spiritual attitudes. The strategies that were run in developing the ability of spiritual attitudes was by prayer activities before and after the learning process, by visiting places of worship, familiarizing $3 \mathrm{~S}$ (smiles, shake hands, greetings.
\end{abstract}

Keyword: Best strategies, developing, Student spiritual attitude.

\section{Introduction}

Strategic Efforts of Christian Religious Education Lecturers. Understanding Strategy that is a real plan regarding a process of activities that can be achieved to the target specifically as expected. So the strategy is basically that the steps are meaningful broad and deep that can be generated from a learning process and from the results of deep thought and reflection based on theories and personality experiences. In general, the strategy is defined as the basic outlines of the direction to be able to act in a business that can be achieved on certain targets. Therefore, education requires a deep strategy in the learning process so that Christian religious education in the formation of an attitude of spirituality can run well by looking at the situations and conditions that exist in the environment. In this case it can indicate that the role of the strategy in achieving the specified goals is very important. Therefore, before deciding on a strategy, it is necessary to set clear goals that can be measured for success as the goal is the spirit in the implementation of strategy strategies. So some of the notions that have been described are that it can be concluded that the strategy is part of the planning that contains the activities and can be designed as such in order to achieve the expected goals. In this case, the strategy carried out by the educator or concerned in achieving the expected educational goals.

Understanding Educators (Lecturers) Christian Religious Education. When discussing the issue of education, of course there must be the word "educator" that cannot be separated. So because, educators (lecturers), including people who have a very large contribution to the implementation of education whose name is national. Educators (lecturers) are also considered as toars or human figures in providing education. Because it is 
not surprising, if the world of education is a world where the educator must be a role model to emit the light of truth values according to the standard of truth that an educator must teach the values of truth so as not to save the right path (Proverbs 22.6).

\section{Methodology}

The method used to gain the data was firstly by preliminary study, of which the researcher had an observation towards the students of PAK department at IAKN Tarutung concerning on their character, generally. Furthermore, it was proceeded by conducting an interview against the sample who had been chosen by random sampling upon the 6 classes of the forth semester of PAK department in academic year of 20172018 , with the total students of 180 as the population. The obtained data (the result of the interview) then collected and administered to analyze. In data analysis, all the responses were tabulated and classified into 2 standard namely whether the response belonged to positive attitude or negative attitude based on the indicators of the scoring rubric that were found in the table below:

Table 1. Rubric of Interview

\begin{tabular}{|c|c|c|c|c|}
\hline $\mathrm{NO}$ & STUDENTS NAME & RESPONSES & POSSITIVE ATTITUDE & NEGATIVE ATTITUDE \\
\hline 1 & Roysaputra S & yes & $\checkmark$ & - \\
\hline 2 & Lewina & yes & $\checkmark$ & - \\
\hline 3 & Exaudi & yes & $\checkmark$ & - \\
\hline 4 & Yenni & yes & $\checkmark$ & - \\
\hline 5 & Bella & yes & $\checkmark$ & - \\
\hline 6 & Moreyta & yes & $\checkmark$ & - \\
\hline 7 & Tiorinta & yes & $\checkmark$ & - \\
\hline 8 & Ruben & yes & $\checkmark$ & - \\
\hline 9 & Mikel & yes & $\checkmark$ & - \\
\hline 10 & Meta & yes & $\checkmark$ & - \\
\hline 11 & Lasma & yes & $\checkmark$ & - \\
\hline 12 & Risma & yes & $\checkmark$ & - \\
\hline 13 & Rynelsi & yes & $\checkmark$ & - \\
\hline 14 & Sarah barus & yes & $\checkmark$ & - \\
\hline 15 & Christin & yes & $\checkmark$ & - \\
\hline 16 & Sabda 1 & yes & $\checkmark$ & - \\
\hline 17 & Elisabet L & yes & $\checkmark$ & - \\
\hline 18 & Carlos M & yes & $\checkmark$ & - \\
\hline 19 & Serli & yes & $\checkmark$ & - \\
\hline 20 & Stevan & yes & $\checkmark$ & - \\
\hline 21 & Siska & yes & $\checkmark$ & - \\
\hline 22 & Marcy & yes & $\checkmark$ & - \\
\hline 23 & Dosnita & yes & $\checkmark$ & - \\
\hline 24 & Rossy & yes & $\checkmark$ & - \\
\hline 25 & Eva & yes & $\checkmark$ & - \\
\hline 26 & Rosty & yes & $\checkmark$ & - \\
\hline 27 & Sani & yes & $\checkmark$ & - \\
\hline 28 & Antonius & yes & $\checkmark$ & - \\
\hline 29 & Citra & yes & $\checkmark$ & - \\
\hline 30 & Feny & yes & $\checkmark$ & - \\
\hline
\end{tabular}

Possitive Attitude Indicators:

1. Using proper words to show kindness and worth

2 . The words figure out good attitude 
3. The answer is expressed heartedly as the own responses

4. It is not under pressure

Negative Attitude Indicator:

1. Using rigid words to show rude characters

2. The words figure out weak/bad attitudes

3. The answer is expressed as if subsconciously

4. It seems under pressure

\section{Discussion}

Independent and responsible are essentially in the hands of educators, because an educator is said to succeed in teaching or educating when his educators succeeded in exceeding their knowledge compared to and fearing the commands of Allah Almighty with educator. Because, the figure of educators (lecturers, teachers) has a strategic role in "measuring" students to be smart, intelligent, skilled, moral and knowledgeable. In this case also must have a person who has the task to form a sapling of student spirituality by adapting the power of the almighty. Educators can be interpreted as people who are tasked with relating to educating the spirituality of national life in all aspects, both spiritual, emotional, intellectual, and other aspects related to Pancasila and religious values. Because a very noble task is if an educator has a high position and become a role model for everyone who needs it. Educators (lecturers) are the most mature people who are responsible for giving assistance to students in developing their body and spirit, so that they can reach maturity, be able to stand on themselves and fulfill their abilities

In the case of Christian Religious Education, educators are called, among others, namely: Educators know the character of students; Educators (Lecturers) must always try to improve their talents both in the fields taught and in educating them; Educators must transfer their knowledge, do not make difficulties with the knowledge that has been given or educated.

In the Bible explains that the task of educators is that can be concluded with the knowledge that has been taught, namely: Following in the footsteps of the Imams or educators who can be experienced in their duties, obligations; Be a role model for students; Have a code of ethics for educators or lecturers, teachers

The task of the lecturer or teacher as a translation of the mission and functions it has, according to Darji Dharmodiharjo's book are three things: educating, teaching, and training. The task of educating more emphasis on the formation of the soul, character, personality based on religious values and Pancasila; teaching assignments emphasize the development of reasoning abilities, and train more emphasis on developing the ability to apply technology by training various skills. But the striking difference is that Christian Religious Education lecturers take a direct approach to the formation of spirituality of student behavior in accordance with Christian values. Lecturers of Christian Religious Education not only teach theoretical Christian religious education material, but more than that is the way that Christian Religious Education materials can be absorbed by students. And has a very noble spirituality.

Strategies of Christian Religious Education Lecturers in Developing spiritual attitude abilities. In a sense that is the spiritual attitude to form students who are faithful, independent, democratic, and responsible. There are four aspects of the teacher's job potential to improve group learning outcomes into abilities, namely; The teacher must plan a teaching and learning program; Carry out and manage the teaching and learning process; 
The teacher must give or assess the ability of the teaching and learning process; and Mastering the subject matter in mastering the fields or lessons that are taught. So that the strategy of learning in sharpening spiritual attitude is by obtaining a meaningful result of assessment by proper person who responsible in. Attitude is an internal ability that plays an important role in making good decisions and must be an example or model.

a) Demonstrate example, an example is to give ourselves to be salt and the light of the world like the apostle Paul is to give ourselves to be a role model for every human being.

b) Give bombing, parental guidance for children is very important and vice versa to the teacher to his students is done by giving reasons that make sense like discussions

c) Encouragement, advice is the strength that motivates children in activities to do something that can be achieved in the objectives of the activity.

d) Guidance, in teaching teachers should be able to transfer their knowledge to the practical world, especially to millennial children

e) Heart or Mind, spiritual strength is located in the straightness and purity of conscience, mind, soul and emotional. The lecturer must educate the student to be able to guide the spiritual that already exists in the students so that his mind remains clear or clear.

In the 2013 curriculum, so of course familiar with the term competency. In this millennial era, it does not only require skilled people, but who have personalities that share and have love, which is why, it is necessary to develop competencies in each student so that they are directed to become students who are broad-minded, skilled and have personalities that can exemplified, could be a role model.

Competence consists of acts of full intelligence for anyone to possess as a condition or standard for judging his capability in carrying out tasks in particular field of work, competencies relating to religious attitudes must be developed indirectly when students are studying science.

\section{Conclusions}

From the research result, it seemed that organizing and sharpening spiritual attitude of learners is not a simple task to do, there are many aspects that should be think over regarding the learners improvement in all sides of their competences. Improving spiritual question of the learners is one of the educators way to sharpen the learners ability to manage their attitude as their affective domain, which leading one's ability on how to act and behave upon self personality, social life, and upon God as his Creator.

The strategy used by Christian religious education educators in developing spiritual attitudes is done through familiarizing the learners to own habitual activities such as : prayer activities before and after the activity process. Meanwhile, to evaluate the spiritual attitude of the educator, the lecturer using the observation approach, driven extra worship at the campus, and counseling for the students. 


\section{References}

[1] Hossein, Nasr, Sayyed. 1991. Islamic Spirituality. New York: Crossroad.

[2] Majid, Abdul, Learning Planning Developing Teacher Competency Standards (Bandung: PT Remaja Rosdakarya, 2007)

[3] Marshall, Ian, SQ: Utilizing Spiritual Intelligence in Integralistic and Holistic Thinking to Mean Life, Bandung: Mizan.

[4] Mujtahid, Teacher Professional Development, (Malang: UIN-Maliki Pres, (2011)

[5] Mulyasa, E., Development and Implementation of the 2013 Curriculum, (Bandung: PT Remaja Rosdakarya, 2013)

[6] Sanjaya, Wina, Standard Oriented Learning Strategy of the educational process, Ed. 1., cet. 8, (Jakarta: Kencana, 2011)

[7] Sardiman, A.M (ed). 2003. Teaching and Learning Interaction and Motivation. Jakarta: PT. Raja Grafindo Persada

[8] Sudjana, Nana, Basics of the teaching and learning process, (Bandung: Sinar Baru Offset, 1989) 